\title{
‘DEMOCRATIZING' PUBLIC SERVICES? REPRESENTATION AND ELECTIONS IN THE SCOTTISH NHS
}

\author{
SCOTT L. GREER, IAIN WILSON, ELLEN STEWART AND PETER D. DONNELLY
}

In representative democracies most public administration is actually directed by unelected appointees. These appointees are accountable to voters only indirectly through a minister. In Scotland, many decisions on healthcare provision are made by regional health boards. The Scottish government authorized experimental elections to two of these health boards in the hope of democratizing health service administration. Our research uncovered many unexpected consequences of holding direct elections to health boards, but they did not revolutionize the accountability structure in the ways we might have expected. New members largely accepted inherited norms which discouraged them from acting as conduits for public opinion.

\section{INTRODUCTION}

In theory, the democratic responsiveness of public healthcare providers is clear: it runs to the government, which is accountable to the legislature, which is in turn accountable to voters. Voters who are dissatisfied with the decisions of local managers can oust their elected representatives. Government ministers, knowing this, will try to make local public sector managers responsive to voters.

This relationship has not always worked so well in practice. A major reason is the distance between the decisions of local managers and the forces that affect governments. Local managers might not pay enough attention to local politics; they might take decisions that fit with national policy but incur local opposition. Ministers can make policies that are unpopular at the local level. Managers who are accountable to a national politician can make decisions that leave local populations feeling excluded or discontented.

One common solution is to have local organizations conduct extensive engagement efforts that solicit community opinions on upcoming decisions and priorities without invoking existing (partisan) political routes of engagement (Warren 2009). Done well, this offers the prospect of avoiding political problems and better serving community needs. The NHS and other public sector organizations devote considerable resources to consulting, surveying, and building relationships with local populations. In the UK NHS these activities are referred to as public involvement, an agenda closely associated with New Labour governments of 1997-2010 (Andersson et al. 2006). Keeping managers well informed about community preferences and priorities does not, however, solve problems of accountability. Community will can be hard to gauge and communities frequently split - as when two hospitals or police stations are to be merged, creating a zero-sum contest between towns. The accountability of managers is still upwards and accountability for national priorities might outweigh local discontent.

What are the alternatives? One option, the subject of many experiments and studies in England, has been to give patients an exit option (Dowding and John 2011). A second is to make a service part of the remit of elected general-purpose local governments.

Scott L. Greer is in the School of Public Health at the University of Michigan, Ann Arbor, USA. Iain Wilson is in the Department of Politics and International Relations, University of Edinburgh, UK. Ellen Stewart is in the Centre for Population Health Sciences, University of Edinburgh, UK. Peter D. Donnelly is in the School of Medicine, University of St Andrews, UK. 
Most NHS systems have not chosen to do this (Adolph et al. 2012) and ones that have, mostly in Scandinavia, are recentralizing (Magnussen and Martinussen 2013).

A third alternative is direct local elections for the specific service. As an option for central government, introducing a layer of elected representatives to run local public services, holds a number of attractions - and risks. On the one hand, will a broad range of people run for office, and vote, and contribute to decisions that make the health service more responsive to local populations in their entirety, thereby promoting a broader citizenship in which communities take responsibility for health? On the other hand, in every case warnings are made that services will be taken over by special interests, perhaps through lack of candidate and voter interest (as in Marmor and Klein 2012), or will be financially irresponsible and populist, or exclude minority groups, or tangle lines of accountability by starting fights with the ministers to whom they are still accountable for the money they spend.

Elections to subordinate bodies can generate, rather than resolve, contradictions, as when central government proclaims elections to empower local communities but then treats newly elected bodies as primarily accountable upwards, to the centre, rather than downwards, to the community. Nonetheless, this approach is increasingly fashionable. It is still most common in the United States, where local government might be flanked by elected administrators of roads, police, schools, sewers, transit, library, and other services (Berry 2009). In England and Wales it has meant elected police commissioners (Sampson 2012). In NHS systems it can mean elections to local health organizations. This has been tried in England (Allen et al. 2012), New Zealand (Gauld 2005), some Canadian provinces (Eakin 1984; Lomas 2001), and - in 2010 - two Scottish Health Boards (Greer et al. 2012).

This article exploits data from those Scottish elections. We wanted to know whether a broad range of people participated in the elections, whether different (kinds of) people were elected than would have been appointed, and whether elected members felt greater pressure to be responsive to public opinion. In this case, neither boards' demographics, nor members' perceptions of their roles, nor their behaviour suggested a real transformation, even when some new members sought change. Boards avoided potential problems of conflicting accountabilities at the local and national levels, but this largely reflected elected members' limited engagement with the public. Elections did not bring the kind of popular democracy anticipated by proponents.

\section{SCOTTISH HEALTH BOARD ELECTIONS}

Scotland's NHS, like many British public services, is mostly run by organizations with appointed boards (Skelcher 1998). These are called Health Boards, or more commonly 'NHS [region]', for example NHS Fife. Health Boards are the basic organizations of the NHS in Scotland. They are integrated providers of virtually all healthcare in their geographic regions. Boards are effectively the middle management tier of Scottish healthcare; they are funded by and obey instructions from the government, including financial and care quality targets (Greer 2004). Between their existing obligations, financial and legal dependence on the government, and specific targets, they can seem powerless - but attaining those objectives and carrying out their assigned tasks involves making decisions of great consequence about investments, the location of facilities, or even the availability of some services.

Outside the pilot areas, boards have appointed governing boards made up of a mixture of non-executive directors chosen by the minister and ex-officio executive directors (NHS managers on the board, such as the Chief Executive and Medical Director). These are

Public Administration Vol. 92, No. 4, 2014 (1090-1105)

(C) 2014 John Wiley \& Sons Ltd. 
responsible, under very clear and much-rehearsed norms found throughout the UK public sector, for 'strategy' and 'governance' (Committee on Standards in Public Life 1995). The non-executive directors are not supposed to involve themselves in 'operational matters', which remain the responsibility of designated executives, though non-executives can quietly raise issues with executive directors and, in times of crisis, the distinction between strategic and operational can become blurred. Nor, in practice, do they fulfil an 'external role' (Skelcher 1998, p. 104) dealing with the public and other stakeholders, except in a quasi-ceremonial figurehead capacity.

In standard public appointments procedures in Scotland, organizations advertise for non-executive board members using a 'skills matrix', which specifies required skills such as finance or expertise with corporate governance and narrows the applicant pool to people with those skills. Applicants are interviewed by a separate agency, the Office of the Commissioner of Public Appointments in Scotland, whose reports are summarized by civil servants before being presented to ministers. The process minimizes the risk of ministers appointing incompetent candidates. The posts are part-time, and only modestly paid. The process, and the limited pay, is perceived as filtering out people who diverge from a single type: late-career or recently retired professionals, usually white and often men (the phrase 'pale, stale, and male' (Flinders et al. 2011) is widespread in the Scottish public sector and was used by several interviewees). And they are formally accountable only to the Scottish government. At the official induction for elected members, Health Secretary Nicola Sturgeon stated explicitly that the basic accountability relationship would not change: she expected that boards would remain accountable to her, despite a majority of their members being elected.

A move to democratize boards followed several elections in which local hospital disputes loomed large. The Scottish National Party (SNP) adopted the principle that the boards should be elected by local residents while in opposition. When the 2007 elections did not produce a majority for any single party, the SNP formed a minority government which was only able to legislate for a pilot. The Health Boards (Membership and Elections) (Scotland) Act 2009 ordered a plurality of members of two of Scotland's 14 regional boards, NHS Dumfries and Galloway (NHS D\&G) and NHS Fife, to be directly elected. The elected members would displace some Scottish government appointees.

The Bill set three evaluation criteria for these pilots:

i. the level of public participation in the Health Board elections,

ii. whether having elected members on Health Boards led to increased engagement with patients and other members of the public or improved local accountability of the Health Board in the specified Health Board areas, and

iii. the cost of holding the Health Board elections and the estimated cost of holding future Health Board elections in all Health Board areas. (Scottish Parliament 2009, our emphasis)

The elections themselves were by postal vote, using the Single Transferable Vote system with the whole of each board area as a single ward. Each candidate composed a 250-word election address in which campaign promises were acceptable. Unusually, some 16- and 17-year olds (those born after November 1993 who were pre-registered) could both vote and stand as candidates. Election expenditures were limited to $£ 250$; to put this figure in context, over 350,000 people live in Fife. Between 8 and 13 May 2010, local Returning Officers issued voting packs to eligible voters. The voting packs included the election statements, listed alphabetically, and a ballot paper. Polls closed at $4 \mathrm{pm}$ on 10 June 2010. The elected members, together with councillors nominated by local authorities, constituted a 
majority on both boards. The remainder of each board was still composed of executive directors and a few remaining appointed non-executives.

\section{DEMOCRATIZATION}

We wondered whether elections, in the absence of other changes, significantly altered the democratic responsiveness of local health boards. This, inevitably, raised the difficult question of what makes governance 'democratic'. While acknowledging the wide range of potential rationales for introducing elections to public services, this article grounds itself in contemporary democratic theory. Urbinati and Warren (2008, p. 396), drawing on Pitkin (1967), summarize the discussion by presenting the democratizing effects of elections as a product of authorization and accountability: 'democratic responsiveness includes, in one way or another, (a) authorization of a representative by those who would be represented, and (b) accountability of the representative to those represented'. These fit neatly with our observations, with elected members drawing distinctions between their relationships to local populations at the point of election and after they were in place.

For Pitkin, and Urbinati and Warren, 'democratic' governance, within a representative framework, emerges partly from representatives being authorized by the population. Meaningful authorization requires more than the simple fact of an election taking place. Where elected personnel are expected to work for a population, in this case the whole population of the Health Board areas, they need to receive authorization from an acceptable share of that population. An election in which only a tiny minority chose to vote, or from which important groups within the population were excluded, would be questionable - although how severely participation can be skewed and still provide meaningful authorization to the victors is, and will remain, controversial. Furthermore, voters cannot be put in a position of simply picking names at random, but need to be making judgments about who should act in their name. Therefore, electors need to be informed about the election so that groups not already closely involved in decision-making understand its significance and voters can make meaningful choices. For the Health Board elections, we wanted to know whether different people were elected than would otherwise have been appointed, whether there was widespread participation in the elections, and whether voters understood what they were asked to decide.

Authorization is not sufficient. Crucially, once representatives are in place they also need to be accountable to the broader population. Whether the elected members received meaningful authorization was obviously important, but much of this importance was that it shaped the members' understanding of how it would be appropriate to behave once in office. Because these were pilot elections the Scottish government was not bound to hold elections to fill these same positions again, so it was unclear whether the voters would have access to one of the most important formal mechanisms for holding elected members to account - the chance to decide re-election for another term. ${ }^{1}$ If elected members were to differ from appointees as regards accountability, the difference would primarily be informal, resting on differences in how members construed their roles and responsibilities, and who they perceived themselves as accountable to. A major attraction of Urbinati and Warren's (2008) analysis is that it emphasizes these informal and subjective aspects of democratization, as opposed to a focus on re-election. While Urbinati and Warren (2008, p. 396) argue that an accountability relationship must include a sanction in case the representative fails or misbehaves, being denied re-election does not seem to be the only possible sanction. In fact, we wanted to know whether elected members felt informal pressure to act for the general public. 


\section{OUR STUDY}

This stress on elected members' perceptions of their roles implied that we needed to combine qualitative and quantitative methods.

At a quantitative level we examined turnout in the elections using official records and by conducting our own surveys of electors in each Health Board area. We sent 3,000 forms to registered electors in Fife and 3,000 to Dumfries and Galloway, gathering 785 and 1,017 responses, respectively. This represents a 31 per cent overall response rate once we take into account survey forms returned undelivered. We used a second questionnaire to collect demographic information on both successful and unsuccessful candidates. These responses gave us a good sense of how far voters, candidates, and victors in the elections resembled the populations.

Numbers could not tell us the whole story, because democratization is largely a matter of how representatives and populations perceive roles, relationships, and motives. We needed actors to explain these subtle reactions to the situation in their own words. We interviewed 85 of 130 candidates in the elections and 20 electors to get a sense of how they saw that relationship. The 85 included all the candidates who consented to interview, but the 20 electors were not intended to be a statistically representative sample. Not all electors who returned survey forms gave us permission for further contact, but of those who did we sought demographic and geographic diversity which meant seeking out minorities (ethnic, disabled, younger electors) and balancing voters and non-voters living in urban and rural, rich and poor areas across both boards. We were particularly interested in the small number of respondents who reported voting in the Health Board election but not the General Election a few weeks earlier.

Interviews with electors focused on their views on the election and Health Board, while we asked candidates about their background as well as their motives for seeking election and expectations about the role. Our topic guides are reproduced as Appendix 1 (online version of article). Following the elections, we observed board meetings for over a year. We also continued to interview board members, interviewing a total of 55 between March 2010 and March 2012. We requested interviews with all elected non-executives, all existing non-executives, and most executive members of each board. We are confident that there are no significant omissions in our qualitative sampling. These interviews focused on how individuals saw the role of the board, their own role within that, and their experiences of the pilot.

\section{AUTHORIZATION}

While it is possible to argue on principle that any election is more democratic than appointment by a minister, that seems a rather low threshold to justify the expense of elections and disruption to existing recruitment techniques that have their own virtues (such as skills matrices and formal checks for conflicts of interest). Do elected members come from, and have the support of, a wide range of people within the community, or demographically and ideologically narrow segments? Elections do not guarantee victors who resemble their community in gender, ethnicity, or class (Norris and Lovenduski 1995; Krook 2010). Demographics are not destiny, and demographic representativeness does not necessarily represent democratic governance (Pitkin 1967). But in this case, where the norm prior to the election was for a narrow segment of the population to become involved, demographics tell us something about how far the elections widened the relationship between boards and populations. Widespread participation is often taken as a sign of engagement, 

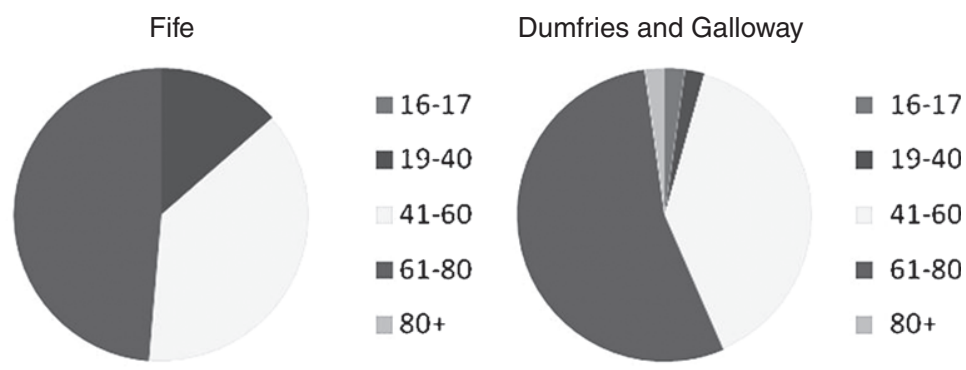

FIGURE 1 Candidates by age

while particularly low and skewed turnout is often symptomatic of underlying problems.

\section{Candidates, voters, and victors}

Many of the candidates we spoke to mentioned that they were attracted by the election and would not have applied for appointment, sometimes due to ignorance of the possibility, sometimes due to opposition to the principle, and sometimes because they believed appointing panels sought a specific type of person. This suggests that an appointment round would have attracted a different pool of candidates. However, at the level of demographic characteristics the elections selected candidates who resembled previous appointees.

Our survey of candidates, completed by 83 of 130 candidates (64 per cent), showed that they were 96 per cent white (one chose another ethnicity, the others did not declare) and 71.1 per cent male. Although we did not ask directly about economic status, checking candidates' postcodes against the Scottish Index of Multiple Deprivation (Scottish Government 2010) suggested that they came disproportionately from affluent areas. Interviews with all the candidates willing to speak to us (85 of130) revealed that most were semi-retired or retired professionals, frequently with NHS experience during their careers. The age profile of candidates was striking: 36 per cent were aged between 41 and 60, and 51.8 per cent were aged between 61 and $80^{2}$ (Figure 1). Candidates were much older than the population average (Figure 2).
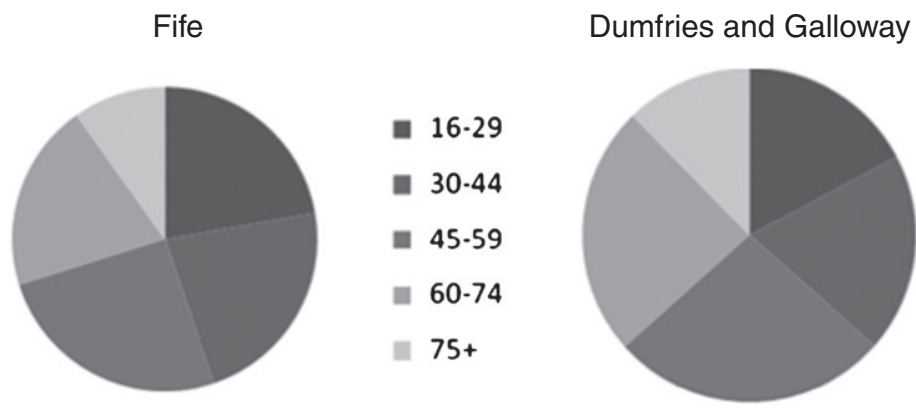

FIGURE 2 Age structure of populations, excluding under-16s

Note that the best available data, from the 2011 census, used different age bands from our survey (National Records of Scotland 2012a, 2012b). 
This was not a result of interest groups filtering candidates. Few candidates mentioned party affiliations, though a few benefitted from party networks and name recognition. A few candidates, mostly with local experience, campaigned door to door and used leaflets, and others were connected with particularly vigorous networks (such as public sector trade unions and local medical professionals), but most did not take any measures beyond writing their 250 -word electoral address and perhaps notifying their social circles. This was not an election in which vested interests made concerted efforts to capture boards. On the other hand, this also meant that most candidates did not have access to established mechanisms for measuring or mobilizing public opinion. This had important consequences for the successful candidates' ability to claim that they reflected public opinion, and may also have fed into low turnout.

Turnout overall was 22.6 per cent in Dumfries and Galloway, and 13.9 per cent in Fife. While low, this is not disastrously low: for comparison, in the most recent local authority elections in Scotland average turnout was 39.7 per cent (Liddell et al. 2012, p. 10). The results from our survey of registered electors allowed us to estimate how reflective these voters were of the population served by each board. The results showed that turnout was not predicted by deprivation, gender, state of health, or disability. ${ }^{3}$ What did stand out was age. Older respondents were much more likely to have voted: in fact, an elector aged between 60 and 80 was more than twice as likely to vote as an elector aged between 18 and 40. ${ }^{4}$ The official election records showed that turnout among registered electors under 18 was as low as 7 per cent in Fife. While the elected members were authorized by an election, this was an election dominated by the old.

The elections also tended to be won by older candidates. The age profile of winners was similar to that of the electors and the overall candidate pool: one-third 41-60, two-thirds 61-80. All of the elected candidates were white. Both NHS Fife and NHS D\&G have very large white majorities, and there was only one non-white candidate (two did not state their ethnicity), so it is not obvious that ethnic minorities were underrepresented. But the elected did seem to be better-educated than the population as a whole, with more formal qualifications than is typical among the population (Greer et al. 2012, p. 23).

In summary, the elections attracted candidates who tended to be older, white, male, and semi-retired or retired. The voters similarly tended to be much older than the population as a whole. The winning candidates were also much older than the population, and better-educated. The elected members were similar demographically to appointed members, fitting the pattern in other health systems which have instituted direct elections (Laugesen and Gauld 2012).

\section{Information}

Voters may select candidates from overrepresented demographics without calling the validity of their authorization into question. Electors may freely choose to abstain. But if those choices are constrained by the way the election is organized, that may be significant for claims of democratization. A common worry is that authorization is devalued where people lack meaningful choices.

Non-executives within the Scottish NHS rarely become well known as board members, and most receive little or no publicity. Voters we interviewed could not name them, even after the elections, unless they happened to be close friends or relatives, and most had little or no idea of what the governing boards actually did. The 250 -word statement from each of the candidates offered little help, because the amount of reading was overwhelming (with 
TABLE 1 Self-rated information on the Health Board and General Elections (data from Greer et al. 2012)

\begin{tabular}{|c|c|c|c|c|}
\hline & \multicolumn{2}{|c|}{ Health Board Election } & \multicolumn{2}{|c|}{ General Election } \\
\hline & $\begin{array}{l}\text { Dumfries and } \\
\text { Galloway }\end{array}$ & Fife & $\begin{array}{l}\text { Dumfries and } \\
\text { Galloway }\end{array}$ & Fife \\
\hline 'Not at all well informed' & $27 \%$ & $42 \%$ & $5 \%$ & $6 \%$ \\
\hline 'Not very well informed' & $39 \%$ & $40 \%$ & $17 \%$ & $20 \%$ \\
\hline 'Well informed' & $29 \%$ & $17 \%$ & $63 \%$ & $60 \%$ \\
\hline 'Very well informed' & $4 \%$ & $1 \%$ & $16 \%$ & $14 \%$ \\
\hline
\end{tabular}

so many candidates the booklets ran to over 10,000 words of small print) and electors had little sense of what criteria they should use to pick a non-executive. As one elector put it:

\begin{abstract}
With elections for national government and the Scottish Government and for local government I suppose because they happen more often you know what sort of role the elected people will have and what sort of decisions they'd be making, but I didn't know much about how the Health Board worked and what the elected members were supposed to be doing. I was very surprised that there was no information provided about that so you were basically asked to choose names at random with no notice of what the positions were. (Non-voter, Fife)
\end{abstract}

The contrast was even more striking when compared to their feelings about the General Election just a few weeks earlier (Table 1).

This was clearly far removed from the ideal of democratic authorization, which centres on voters making informed choices among candidates. Voters remained uninformed about the organization for which they were selecting candidates, which is understandable given health boards' lack of public exposure, and most had little information about the candidates. This meant that most were unlikely to follow the elected members' future careers and seek to use them to transmit their will to the board.

\title{
ACCOUNTABILITY
}

In sophisticated theories of democracy, authorization is far from the end of the story. Although the candidates, voters, and victors in many ways resembled the appointed members they were displacing, and the elections did not establish wide public interest in their activities, they could still have reshaped relationships. Newly elected board members might still have interpreted their roles differently from either the non-executive directors on the boards before the elections or the executives. The boards might have become more ideologically diverse. Members might have channelled public opinion in a way appointees cannot. They might see themselves as personally accountable for delivering campaign pledges opposed by other members. We needed to identify any differences between how elected and non-elected directors viewed their roles, and how they acted on the board.

\section{Non-executive director roles}

Did newly elected non-executive directors understand the role of non-executive directors, or the board in general, differently? Did the presence of the directly elected non-executive directors change others' interpretation of the role of the board?

Because perceptions were so important here, we interviewed all 25 elected members several months into their terms. We also spoke with 30 other key members of the boards both 
before and after the elections, to get their views on what changed. Our interviews found that most elected directors accepted the basic role they inherited (and which was clearly put to them at their induction). The principle that boards were corporate bodies, without government and opposition, and without public dissent after decisions were taken, was accepted by almost all:

If it has been agreed by the board, it's a board decision and I'm part of that board. You can't play it two ways. If you can't argue your case on the board enough to be, you know, convincing, then if it's a board decision, I would agree with it. (Elected board member)

Any decisions that are made, I might not agree with them but I've had my say in Board. I don't go outwith the Board and say 'oh that's terrible, well [the] Health Board's not doing it, not serving the public the way they should'. (Elected board member)

Likewise, most elected board members said they did not see themselves representing geographic areas or specific occupational groups or users. Many described a generic 'public' or 'service user' interest:

I suppose self representing, just an ordinary person, an NHS user perhaps, a parent you know that sort of person. (Elected board member)

There were only a few who did not substantially adopt this interpretation, and only one who clearly and publicly broke with it. They are worth analysing as deviant cases (Glaser and Strauss 1967): all had previous political experience and were accustomed to seeking visibility and campaigning. Even among the directly elected members with political and campaigning experience, which included local government office and contesting seats in the UK Parliament, most accepted the traditional interpretation of board members' roles.

The most visible way to dissent from inherited norms was speaking to the media without clearance from communications staff. Only a few spoke to journalists at all, and only one systematically used the press to challenge the board. In Fife, a few experienced members continued to speak to the press in consultation with the executives and board communications staff. Most board members, when asked, explained that they did not wish to deal with the media and did not see it as their job to do so. However, one board member in Dumfries and Galloway not only talked to journalists but also wrote letters to the editor dissenting from board decisions and assisted campaigning groups which had a contentious relationship with the board (for example, organizing a speech by a campaigner against local hospital closures). This was quite consistent with the candidate's promises; her electoral address began 'STOP COMMUNITY HOSPITAL CLOSURES!' (capital letters hers).

Another way to express dissent was to break with an informal norm of consensual decision-making that had held in both boards. In Dumfries and Galloway, and to a lesser extent in Fife, members sometimes publicized their individual, as opposed to corporate, positions by forcing contested votes and insisting that their individual views be minuted. The members who called for these wanted to make their stance known in part because they felt that they had been elected because of their position on some of the contentious issues. Under the inherited understanding of a corporate body, contested votes and minuted dissent would both have been thought of as undesirable because they could threaten board solidarity.

It is worth stressing that few elected members contested norms about board roles: while many of the elected members had clear political experience, as councillors, Parliamentary candidates, and activists, only one former hospital campaigner actually publicly helped campaigns at odds with the board. That last member, a political party activist who acted most like an opposition politician in a legislature (and therefore least like a member of 
a 'corporate body'), finally resigned from the board and has continued with a variety of campaigns on health issues and for other elected office.

Apart from decision-making, another inherited board norm was about the division between the 'strategic' board, which includes responsibility for 'governance', and 'operational' executive functions. At its most conservative, the strategic approach made it unclear how board members would ever raise new issues, or even if they should; their role could seem to be entirely about evaluating executive directors' proposals and financial statements in committees and the full board.

The arrival of the directly elected board members naturally posed some challenges to this concept of the board member, in which there is no representative function. The ordinary activity of a councillor in local government - learning about a problem with a service such as a broken pavement, promising to investigate and asking an officer to resolve it - was considered deviant when a newly elected board member in Fife tried it. The Chair and Chief Executive explained to the member that such issues were not the place of non-executive directors, and that the most the person could do would be refer the complainant to the established bureaucracy for such matters.

In Dumfries and Galloway there were extended arguments about whether board members could conduct their own surgeries, meeting constituents personally as most elected politicians do. The surgeries proposal challenged several role boundaries. Surgeries tend to be local, and a 'corporate' board should try to avoid geographic favouritism within its area. More importantly, surgeries imply that a board member has the right and power to transmit concerns directly from constituents to the board agenda - a challenge to the reactive 'strategic governance' role of non-executive directors. After long arguments, often conducted publicly in full board meetings, the board decided as a compromise to hold collective 'strategic community engagement sessions', advertised to the public, at which multiple members could meet residents. Several were held; attendance was very low and they were discontinued. ${ }^{5}$

Similarly, it turned out that there was no formal, established way for a non-executive director to bring up issues in full board meetings: the expectation had been that non-executive board members with concerns would quietly bring them to the Chair and perhaps executive directors so that they could feed them into the board process, or raise them in committee meetings. The result was that approval of minutes and the residual 'Any Other Business' item on full board agendas would sometimes turn into extended discussions as a minority of board members tried to raise new issues.

In short, the arrival of directly elected board members challenged a number of established board practices, particularly those relating to the norm of 'corporateness', meaning that a board should look publicly unified, and the norm of the non-executive acting in 'governance' and 'strategy' rather than actively solving problems or setting agendas. It might seem only logical that elected figures would want to have traceable (Arnold 1992), visible, stances and influence, and seek to serve constituents. What is striking, however, is how few members actively sought to renegotiate norms about the role of non-executive members and claim credit for individual performance. The dissenting member in Dumfries and Galloway, who had other disputes with the Chair and executive directors, was the most determined to establish these elements of electoral representation - and had strikingly little support. In Fife, few elected members tried.

One explanation for the reluctance of most elected board members to attempt to define a new role for themselves was that they were quickly confronted with an organizational 
depiction of the breadth and importance of the more conventional functions of scrutiny and oversight.

Part of the baffling stuff was those two days [induction], it was all very academic, it was all quite worrying because it was 'here's things that you end up in jail if you do this' and 'somebody will die and it'll all be your fault' it wasn't very useful, it was quite intimidating. (Elected member, Fife)

The telling moment, I think, came during the first day of induction ... when [Chief Executive] stood up and for an hour and 40 minutes, addressed everyone and told them ... he just went on and on and on, all the responsibilities of the Board and what it does and one can almost see the blood draining from the faces of some of those who had got in perhaps on single issues or had a quite different idea of what the Health Board was about as they heard more and more and more. (Elected member, $D \& G$ )

The sheer volume of bureaucratic responsibility (mostly demanding background reading, preparing for and then asking questions at meetings) was a surprise to many elected members and left little time, or indeed energy, to pursue a different vision of the non-executive role.

With those elected members who remained committed to a more rebellious course of action, board Chairs found themselves responsible for squaring the circle of the corporate need for business as usual and an intake including board members with new - and in a few cases radical - ideas about their roles. Extensive and lengthy induction processes, both national and local, repeatedly emphasized the norms of corporate responsibility and accountability to the Minister. 'Rebellious' elected members who persisted in articulating an alternative, more public-facing role were persuaded otherwise (sometimes by their fellow elected members) or quickly found themselves lacking allies. Elected members were not encouraged to meet as a cohort separate from the rest of the board. This was an attempt to build or preserve board cohesion, but had the side effect of removing the opportunity to organize and press for change.

\section{Substantive decisions}

In terms of substantive decisions, the question is whether adding directly elected members to a board changed the decisions of the board - on the issues that dominate board activities, such as whether to sign off annual accounts, make investments, or reallocate resources. There were relatively few contested issues in the two boards during the study period. In Fife, the elected members participated in a contentious vote about a community pharmacy, and (in committee) debates about primary care services in a small community. There is no obvious counterfactual for the Fife experiences, which were decisions affecting small (though vociferous) populations.

In Dumfries and Galloway, there was a larger concern, which was a set of interlocking proposals to disinvest from small community hospitals and bid for Scottish government funds to rebuild the central hospital in Dumfries. This was in some ways similar to a question of hospital location which had been contentious in Fife some years previously, but which was largely settled before the elections. Community hospital reconfigurations are always politically dangerous (Moon and Brown 2001; Brown 2003; Oborn 2008), and the arrival of elected board members (one a campaigner, others with links to various communities that saw their hospitals as endangered) meant that the bid for funds to rebuild the Dumfries facility was endangered by slow board decisions and extended arguments. Executive officers worried that the Scottish government, despite having selected them for a pilot, would not appreciate that a board with elected members would be more likely to have divisions and discussion than a wholly appointed board with a competing request for funds; in an appointed board, of course, such scheduling problems and divisions would 
be a serious black mark in the eyes of ministers. In the end, the bid did go to the Scottish government on time.

It is not easy to say how the presence of the elected board members changed decisions or agendas in either board. Most agenda items continued to come in the old way, from executives, and were handled in committees. Few contentious issues come to full boards, in keeping with established NHS board arrangements. Given the relative stability of procedural norms surrounding boards' and members' roles, it is perhaps no surprise that changes in substantive decisions are hard to identify. The procedures, which showed such stability, are arguably there to prevent any particular board member exercising undue influence over decisions.

More importantly, the most basic norm of board behaviour - one underpinned by powerful legal and financial mechanisms and career incentives - held. That is the norm that boards are accountable to the minister, the basic trajectory of accountability in every parliamentary system, including Scotland. The Cabinet Secretary (minister) for health made this clear to the directly elected board members and many of the executive directors at the induction for new members - the accountability of boards was to her, and hers was to Parliament. This accountability means that boards must be preoccupied with centrally determined objectives, including targets covering areas such as waiting time limits, infection control performance, and cancer detection as well as financial balance and fiscal and governance accountability (professional malpractice, corruption).

While there was no provision for a Scottish government minister to fire an elected health board member, the executive directors and appointed non-executive directors interested in renewal had a direct career incentive to perform. Of course, fulfilling such objectives is the function of the boards in Scotland, and it would be hard to argue publicly that an elected board could have worse infection or corruption control than others. In New Zealand, which has the longest-running set of elected health boards, studies have found that elected members of health boards were frustrated by the constraints and directions of national policy (Ashton et al. 2005; Barnett and Clayden 2007).

\section{Politicization, interest groups, and party politics}

One major concern before the elections was that boards would become tools of special interests, political parties, or careerists seeking press. Although elections do not usually make boards unmanageable (Stewart et al. 2012), there is some precedent for these concerns, including an ill-fated attempt to introduce elections in Quebec (Eakin 1994). The resilience of norms about roles made the pilot boards inhospitable environments for politics: the directly elected members who took the most basic steps towards a public profile, for example talking to the media, were viewed as problems and requested to desist. Without the ability to develop an independent profile, meet constituents, claim credit, or take oppositional stances, it is hard to see what political aim could be achieved on a board as against in a campaigning or electoral role.

The resilience of those norms was in large part due to the limited challenges to them - from only a few directly elected members, with soft or no support from other directly elected members. As noted earlier, the election process was curiously individualized and members did not arrive with the support of organized campaign groups which could mediate between them and the electorate. It is possible to imagine parties and interest groups selecting ambitious individuals and encouraging them to use board membership to gain a local profile just as opposition councillors or MPs will 'campaign' on local issues by being photographed complaining about a traffic light (Smith 2011). But 
we saw little evidence of such partisan activity. Why were the parties not more interested in running people for office?

The simplest answer is that a vote for pilot board membership was not a priority for any party, given that the elections came very close to the 2010 UK General Election. No party ran formal selections for health board candidates, which would presumably be a necessary step to lending formal support to candidates. People with political experience in all the main Scottish parties ran, but they mostly relied on local recognition and networks rather than formal party endorsement. The relative weight of health boards in the eyes of local political activists was made clear when the Scottish government, in the run-up to the 2011 Scottish elections, enforced a rule that health board members could not be candidates for other elective office. ${ }^{6}$ This meant that candidates had to choose between often unpromising options - contesting seats which in the mechanics of Scottish elections seemed unlikely to lead to office ${ }^{7}-$ and health board membership. Candidates affiliated with Labour and the Green Party resigned, preferring poor odds for election to the Scottish Parliament.

Why was there not more group interest in influencing the elections? In part, this is because a Scottish health board is enmeshed in a wide range of mechanisms designed to promote consultation: with unions (an Area Partnership Forum with union representatives must sign off on most issues headed for a board, including issues as small as changes in laundry service) and with communities (ongoing public and patient engagement efforts that were unaffected by the pilots). Informally, some executive directors are also supposed to explain, if not represent, interests - the Medical Director is to be familiar with medical opinion, the Nursing Director with nursing opinion, etc. Interest groups with staff, patient, or popular support already had many ways to express opinions through established and powerful mechanisms. Partly for this reason, some groups (e.g. the Royal College of Nursing) made it clear that they did not support the idea of elected board members and would not support anybody, including their members, who ran.

\section{CONCLUSION}

It is possible to identify a wide range of potential benefits of election, much rehearsed in the history of democracy: accountability of the powerful to the ordinary, agendas reflecting citizens' preferences, and decision-making processes that harness political ambition to constructive debate. It is harder to see those benefits in elections for intermediate bodies such as health boards, or police commissioners, whose main purpose is to implement centrally determined policy.

The effect of elections on democratic responsiveness in Scottish Health Boards was limited. This may seem surprising. Candidates, including many who were elected, said they would not have applied for appointment, and the ideological profile of the board was broadened by the arrival of several new individuals. These included a noted disability rights activist and a candidate for the Eurosceptic UK Independence Party (very much a minority in Scottish politics) at the recent General Election. But electors, candidates, and victors had demographic profiles comparable to the existing appointed members - largely white, professional, and (semi-)retired. Elections did not make the general public take a much greater interest in the boards, and the elected members rarely established direct relationships with the public. Once on the board, elected members encountered powerful inherited norms about their roles as non-executive directors. Very few of them actively challenged these norms, which included respecting the corporateness (unity) of the board and focusing their attention on governance (making them reactive to executive directors). 
The extent to which the work of boards was the fulfilment of central directives, and in one case bids for centrally distributed funds, limited the scope of potential change; as was repeatedly argued by executive directors in Dumfries and Galloway, the main effect of board dissension would be no new funds for the Dumfries hospital rather than a change in Scottish government policy. It seems that the voters who showed so little regard for the importance of health boards in health policy had a point - presumably in the same way that more autonomous local governments in the UK, which are still largely constrained by central government, also experience low turnout in their elections. Just as politicians, journalists, and scholars run for and write about more powerful governments, voters seem more interested in them.

These outcomes are broadly in keeping with the experiences of elections to health boards outside Scotland, especially the well-studied New Zealand case (Laugesen and Gauld 2012). In Saskatchewan, Canada, amidst a larger reorganization of the health system, the province abolished elected health boards not because they were dysfunctional, but on the grounds that their benefits in accountability and responsiveness were inadequate to justify their costs in staff time and electoral administration (Lomas 2001). New Zealand reported decreasing numbers of candidates and lower turnout in subsequent elections, as was also seen in the similar elections to the boards of Scotland's National Parks (where some wards are uncontested). Elections to foundation trust hospitals in England have notably low turnout, as did Police Commissioner elections in England (Gravelle and Rogers 2011; Sampson 2012). The Scottish government apparently came to the same conclusion, citing low turnout when it terminated this experiment with elected board members (Scottish Government 2013).

The broader lessons for the study of politics return to the difficulty of incorporating 'voice' (see Dowding and John 2011) into the services of a large modern state. Specifically, creating new democratic accountability in the 'middle management' of the state, such as Scottish health boards or English police forces, can be difficult. Democratic authorization is not helped by low-turnout elections that replicate many of the biases of existing structures; democratic accountability is not helped by electing personnel who largely maintain the roles of their predecessors. The kinds of people who might bring greater turnout, authorization, and accountability are unlikely to be attracted by a constrained role in a constrained organization. This at least spares policymakers many of the theoretical consequences of conflicting accountability and authorization within the public services, but also means potential gains in democratic responsiveness are much less likely to be realized.

\section{NOTES}

\footnotetext{
${ }^{1}$ Although it was unclear whether the public would have an opportunity to re-elect members to those specific positions, several members had sought other elective offices in the past or clearly aspired to do so in the future. Unpopular performance on the Health Board could affect other ambitions. On the other hand, while Scotland has many elected offices, there are also many tempting positions in the gift of the Scottish government, to whom elected members (like appointees) could also be seen as accountable.

2 The Office of the Commissioner for Public Appointments in Scotland (OCPAS) publishes a breakdown of the characteristics of people appointed to public bodies. By comparison their figures for 2010/11 show 57.8 per cent of appointees were male, 96.6 per cent white, and 51 per cent over 55 (with a further 25 per cent aged 46-55, 9 per cent 36-45, and only 3 per cent under 35).

${ }^{3}$ Based on a logistic regression in which turnout was the dependent variable and the covariates were age, sex, self-reported health, disability, and the rank of the respondent's postcode on the Scottish Index of Multiple Deprivation (Scottish Government 2010). The significance threshold was set at $\mathrm{p}=0.05$. See also Greer et al. (2012).

${ }^{4}$ These figures are based on survey results weighted to reflect older electors and voters being more likely to return our survey form than younger electors and non-voters; the impact of age was even more dramatic in the raw data.
} 
${ }^{5}$ A Board report concluded that 'Participation by the public ... was variable, but generally poor' (NHSD\&G Board meeting 3 October 2011, item 160).

${ }^{6}$ The rule had existed for some time, and made a certain sense for appointed board members expected to be rather apolitical. Many interviewees suggested that an elected board member should be able to contest an election and only be required to resign upon election, rather than declaration of candidacy.

${ }^{7}$ Ironically, one member who did this did end up in the Scottish Parliament - but this was a highly unexpected result of the unusual turnout pattern in 2011.

\section{SUPPORTING INFORMATION}

\section{Additional supporting information may be found in the online version of this article: Appendix S1 One: Interview Schedules}

\section{REFERENCES}

Adolph, C., S. Greer and E. Massard da Fonseca. 2012. 'Allocation of Authority in European Health Policy', Social Science and Medicine, 75, 9, 1595-603.

Allen, P., J. Keen, J. Wright, P. Dempster, J. Townsend, A. Hutchings, et al. 2012. 'Investigating the Governance of Autonomous Public Hospitals in England: Multi-Site Case Study of NHS Foundation Trusts', Journal of Health Services Research E Policy, 17, Suppl 1.

Andersson, E., J. Tritter and R. Wilson (eds). 2006. Healthy Democracy: The Future of Involvement in Health and Social Care. London: Involve; NHS National Centre for Involvement.

Arnold, D. 1992. The Logic of Congressional Action. New Haven, CT: Yale University Press.

Ashton, T., N. Mays and N. Devlin. 2005. 'Continuity through Change: The Rhetoric and Reality of Health Reform in New Zealand', Social Science and Medicine, 61, 2, 253-62.

Barnett, P. and C. Clayden. 2007. Governance in District Health Boards. Wellington, NZ: Health Services Research Centre.

Berry, C. 2009. Imperfect Union: Representation and Taxation in Multilevel Governments. Cambridge: Cambridge University Press.

Brown, T. 2003. 'Towards an Understanding of Local Protest: Hospital Closure and Community Resistance', Social \& Cultural Geography, 4, 4, 489-506.

Committee on Standards in Public Life. 1995. First Report of the Committee on Standards in Public Life. CM 2850-1. London: HMSO. Dowding, K. and P. John. 2011. 'Voice and Choice in Healthcare in England', Public Administration, 89, 4, 1403-18

Eakin, J. 1984. 'Survival of the Fittest? The Democratization of Hospital Administration in Quebec', International Journal of Health Services, 14, 3, 397-412.

Flinders, M., F. Matthews and C. Eason. 2011. 'Are Public Bodies Still “Male, Pale and Stale”?', Politics, 31, 3, 129-39.

Gauld, R. 2005. 'Delivering Democracy? An Analysis of New Zealand's District Health Board Elections, 2001 and 2004', Australian Health Review: A Publication of the Australian Hospital Association, 29, 3, 345-52.

Glaser, B. and A. Strauss. 1967. Discovery of Grounded Theory: Strategies for Qualitative Research. Chicago, IL: Aldine.

Gravelle, J. and C. Rogers. 2011. 'Commissioning Accountability', Police Journal, 84, 4, 320-32.

Greer, S. 2004. Territorial Politics and Health Policy. Manchester: Manchester University Press.

Greer, S., I. Wilson, E. Stewart and P. Donnelly. 2012. 'Health Board Elections and Alternative Pilots: Final Report of the Statutory Evaluation' (http://www.scotland.gov.uk/Resource/0041/00411358.pdf).

Hough, D. and C. Jeffery. 2003. 'Elections in Multi-Level Systems: Lessons for the UK from Abroad', in R. Hazell (ed.), The State of the Nations 2003: The Third Year of Devolution in the United Kingdom. Exeter: Imprint Academic, pp. 239-62.

Krook, M.-L. 2010. 'Studying Political Representation: A Comparative-Gendered Approach', Perspectives on Politics, 8, 1, $233-40$.

Laugesen, M. and R. Gauld. 2012. Democratic Governance and Health: Hospitals, Politics and Health Policy in New Zealand. Dunedin: Otago University Press.

Liddell, G., R. Burnside, A. Campbell, F. McGrath and I. McIver. 2012. 'SPICe Briefing: Local government elections 2012' (http://www.scottish.parliament.uk/ResearchBriefingsAndFactsheets/S4/SB12-38.pdf; accessed 21 March 2014).

Lomas, J. 2001. 'Past Concerns and Future Roles for Regional Health Boards', Canadian Medical Association Journal, 164, 3, $356-57$.

Magnussen, J. and P.E. Martinussen. 2013. 'From Centralization to Decentralization and Back: Norwegian Health Care in a Nordic Perspective', in J. Costa-Font and S.L. Greer (eds), Federalism and Decentralization in European Health and Social Care. Basingstoke: Palgrave Macmillan.

Marmor, T.R. and R. Klein. 2012. Politics, Health, and Health Care: Selected Essays. New Haven, CT: Yale University Press.

Moon, G. and T. Brown. 2001. 'Closing Barts: Community and Resistance in Contemporary UK Hospital Policy', Environment and Planning D: Society and Space, 19, 1, 43-59.

Oborn, E. 2008. 'Legitimacy of Hospital Reconfiguration: The Controversial Downsizing of Kidderminster Hospital', Journal of Health Services Research \& Policy, 13, Suppl 2, 11-18. 
National Records of Scotland. 2012a. 'Fife Council Area Demographic Factsheet' (http:/ / www.gro-scotland.gov.uk/files2/stats / council-area-data-sheets / fife-factsheet.pdf; accessed 21 March 2014).

National Records of Scotland. 2012b. 'Dumfries and Galloway Council Area Demographic Factsheet' (http://www.gro-scotland. gov.uk/files2/stats/council-area-data-sheets/dumfries-and-galloway-factsheet.pdf; accessed 21 March 2014).

Norris, P. and J. Lovenduski. 1995. Political Recruitment: Gender, Race and Class in the British Parliament. Cambridge: Cambridge University Press.

Pitkin, H. 1967. The Concept of Representation. Berkeley, CA: University of California.

Sampson, F. 2012. 'Hail to the Chief?', Policing, 6, 1, 4-15.

Scottish Government. 2010. The Scottish Index of Multiple Deprivation, available at http:/ / www.scotland.gov.uk/Topics/Statistics / SIMD (accessed 21 March 2014).

Scottish Government. 2013. 'NHS Patient Involvement' (http://news.scotland.gov.uk/News/NHS-patient-involvement-5ec. aspx; accessed 21 March 2014).

Scottish Parliament. 2009. 'Health Boards (Membership and Elections) (Scotland) Act 2009' (http:/ / www.legislation.gov.uk/asp/ 2009/5/pdfs/asp_20090005_en.pdf; accessed 21 March 2014).

Skelcher, C. 1998. The Appointed State: Quasi-Governmental Organisations and Democracy. Buckingham: Open University Press.

Smith, A. 2011. Devolution and the Scottish Conservatives: Banal Activism, Electioneering and the Politics of Irrelevance. Manchester and New York: Manchester University Press.

Stewart, E., with S. Greer, P. Donnelly and I. Wilson. 2012. 'Health Board Elections and Alternative Pilots: Literature Review' (http:/ / www.scotland.gov.uk/Resource/0041/00411336.pdf; accessed 21 March 2014).

Urbinati, N. and M. Warren. 2008. 'The Concept of Representation in Contemporary Democratic Theory', Annual Review of Political Science, $11,387-412$.

Warren, M. 2009. 'Governance-Driven Democratization', Critical Policy Studies, 3, 1, 3-13. 